\title{
Weeding by the herbivorous damselfish Stegastes nigricans in nearly monocultural algae farms
}

\author{
Hiroki Hata*, Makoto Kato
}

Graduate School of Human and Environmental Studies, Kyoto University, Sakyo, Kyoto 606-8501, Japan

\begin{abstract}
Resident herbivorous damselfishes (Pisces: Pomacentridae) exclude other herbivores from their territories and reduce the grazing pressure within these territories. Among the damselfish, Stegastes nigricans is unique in that it manages a virtual monoculture dominated by the erect filamentous rhodophyte Womersleyella setacea, whereas many other herbivorous damselfishes maintain species-rich farms. We observed the behavior of S. nigricans in a lagoon in Okinawa, Japan, and discovered that this species intensively weeded out specific algae. To analyze weeding selectivity, we compared the algae picked up and discarded by $S$. nigricans to the algal assemblage found inside the territory. To examine the digestibility of each algal species, 10 damselfish were collected, and algae removed from their stomachs were compared with those found in the intestine and faeces. Inside their territories, $S$. nigricans selectively weeded out indigestible algae. These algae were latecolonizing species, and the intensive weeding suppressed algal growth beyond early successional stages. Consequently, selective weeding enabled the fish to maintain virtual monocultural farms of a digestible early colonizer, $W$. setacea, inside their territories.
\end{abstract}

KEY WORDS: Stegastes nigricans $\cdot$ Weeding $\cdot$ Algae farm $\cdot$ Virtual monoculture $\cdot$ Womersleyella setacea $\cdot$ Digestibility

\section{INTRODUCTION}

Substrates in coral reefs are sometimes dotted with algae farms that are managed by resident herbivorous damselfishes. Inside the territories of most damselfishes, species-rich assemblages of algae are established by the exclusion of other herbivores and by non-selective feeding, which acts as an intermediate disturbance and prevents any one species from dominating the substrate (Hixon \& Brostoff 1983, 1996, Branch et al. 1992). The damselfish Stegastes nigricans is unique, however, as it maintains virtual monocultures dominated by a filamentous alga (Fig. 1A,B; Hata et al. unpubl.). How $S$. nigricans manages the algae farm in its territory remains unknown.

\footnotetext{
*E-mail: hata@borg.jinkan.kyoto-u.ac.jp
}

Fish lack cellulases and other enzymes necessary for the digestion of plant cell walls (Horn 1992). Since herbivorous damselfishes also lack the morphological or physiological specialization for digesting plant cell walls (Galetto \& Bellwood 1994), algae edible to damselfishes are mainly restricted to cyanophytes and delicate rhodophytes (Lobel 1980, 1981).

The algae farms managed by most damselfishes have high species diversity (Vine 1974, Brawley \& Adey 1977, Lassuy 1980, Lobel 1980, Montgomery 1980a, Hixon \& Brostoff 1983, 1996, Sammarco 1983, Ruyter van Steveninck 1984, Kamura \& Choonhabandit 1986, Hinds \& Ballantine 1987, Russ 1987, Klumpp \& Polunin 1989, Ferreira et al. 1998). However, there is some evidence that territorial damselfishes weed out undesirable algae to encourage the growth of specific species. Lassuy (1980) reported that Stegastes lividus weeded out unidentified macroalgae that were trans- 

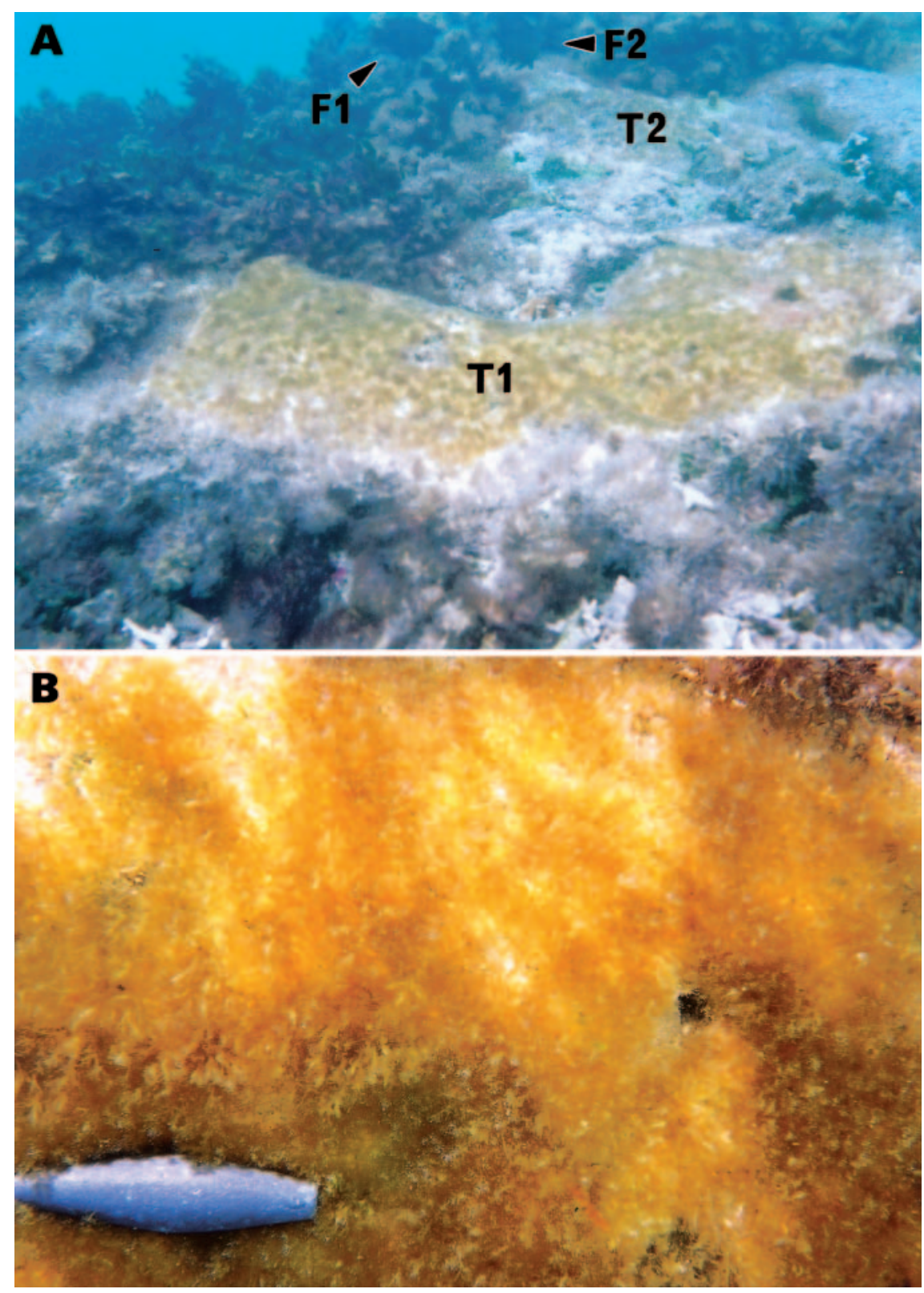

Fig. 1. (A) Two territories (T1 and T2) of Stegastes nigricans (F1 and F2) containing virtual monocultures of an alga; (B) close-up of the territory of $S$. nigricans showing virtual monoculture of Womersleyella setacea. The weight (bottom left of $\mathrm{B}$ ) is used as scale (4 cm long)

planted in its territory. Another herbivorous damselfish, S. planifrons, also selectively weeds out algae transplanted inside its territory (Irvine 1982). Such weeding may contribute to keeping the farms speciesrich. In contrast, it has not yet been demonstrated how $S$. nigricans manages monocultures.

To understand how the monocultures are managed, we observed the behavior of Stegastes nigricans in their territories and examined which species of algae were consumed and which were weeded out. By comparing the composition of algae found in the stomach to that found in the intestine and faeces of $S$. nigricans, we estimated the digestibility of each algal species. Here, we report the intensive and selective weeding of less digestible algae and discuss the effects of weeding on virtual-monoculture maintenance inside the territories of $S$. nigricans.

\section{MATERIALS AND METHODS}

Our study site was located in the windward lagoon on Sesoko Island $\left(26^{\circ} 38^{\prime} \mathrm{N}, 127^{\circ} 52^{\prime} \mathrm{E}\right)$ in the northwestern part of Okinawa, Japan. Twelve adult Stegastes nigricans (10.0 to $14.0 \mathrm{~cm}$ total length [TL]) residing on a coral rock (surface area ca. $10 \mathrm{~m}^{2}$ ) were selected for this study. Seven of these were observed for 10 min each, once or twice every $2 \mathrm{~h}$, from 10:00 to 18:00 h, and every tidal period (high, falling, low, and flowing tide; 21 observations per individual, in total) in September and October 2001, which constituted the non-breeding season (Karino \& Nakazono 1993). We counted the frequency with which a fish picked up and discarded algae, as well as the frequency with which a fish ingested algae. During the same period, we collected the discarded algae and faeces with mesh bags $($ mesh size $=120 \mu \mathrm{m})$. We could successfully collect discarded algae and faeces in calm water-conditions because $S$. nigricans discarded algae and defecated outside the territories, in the water column about $50 \mathrm{~cm}$ above the sea floor. We successfully collected 88 algal samples discarded by 12 damselfish and 29 fecal samples by 6 damselfish. We speared 10 damselfish (9.8 to $14.4 \mathrm{~cm} \mathrm{TL}$ ) in an adjacent area and immediately took them to the laboratory, where we removed the contents of the stomach and intestine. All algae sorted from the discarded pile and the stomach contents were identified to species under a microscope, and the wet weight of each species was measured. Only undigested algae, whose cell contents remained intact, were separated from the fecal and intestinal samples, and the wet 

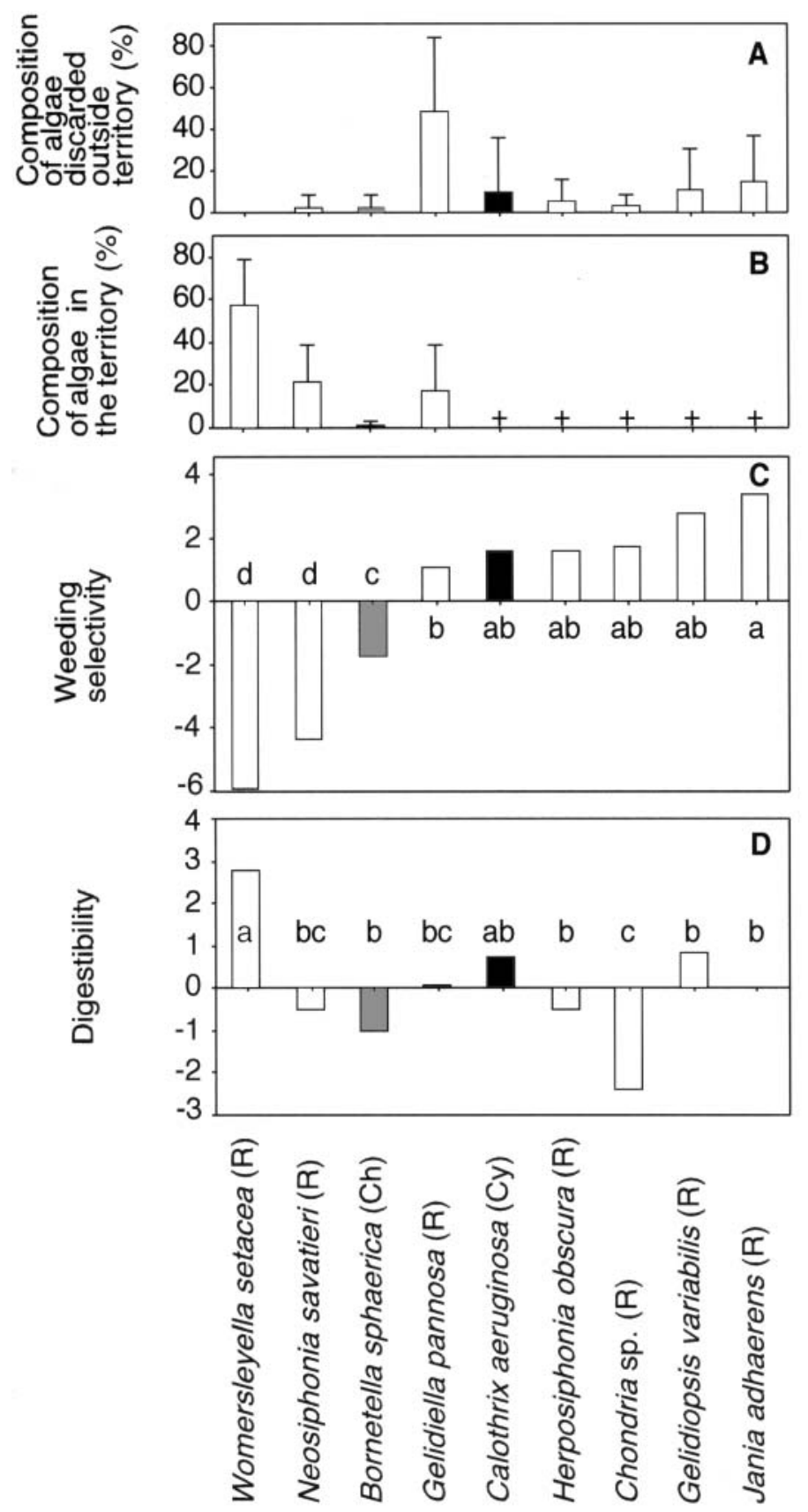

Fig. 2. (A) Species composition in wet weight of algae discarded by Stegastes nigricans; (B) species composition in wet weight of algae in territories of $S$. nigricans; (C) weeding selectivity of 9 species of algae; (D) digestibility of 9 species of algae. Algae species are arranged in order of weeding selectivity. Columns and bars denote means + SD of 12 damselfish in (A), and of 5 territories in (B). Weeding selectivity was estimated as a differential in the ranks of components between discarded algae and algae inside the territories. Digestibility was also estimated as a differential between stomach contents and intestinal/fecal contents. Different letters in (C) and (D) indicate significant differences among algal species (Johnson's [1980] method, Waller-Duncan multiple comparison test: $p<0.05$ ). Letters in parentheses following the species name indicate phyla, R: Rhodophyta; Cy: Cyanophyta, Ch: Chlorophyta weight of each species was measured. All algae in 5 quadrats $(7 \times 7 \mathrm{~cm})$ established in 5 territories on the same coral rock were harvested with a Venturi-suction sampler (McShane \& Smith 1988) in November 1999 and examined for algal composition (Hata et al. unpubl.).

Weeding selectivity was calculated for each algal species by comparing the composition of discarded algae to the composition inside the territories using Johnson's (1980) method. That is, weeding selectivity of an alga was estimated as the differential, averaged across individuals, between the rank of the alga in biomass among discarded algae and the rank inside the territories. The composition of algae discarded from each territory ( $\mathrm{n}=12$ individuals, 88 samples in total) was averaged per individual, while the composition inside a territory was estimated as the average algal composition observed inside 5 territories. We used PREFER version 5.1 (Pankratz 1994) to apply Johnson's method.

We also estimated digestibility of each algal species comparing stomach contents to intestine/fecal contents using Johnson's method. Because this method is appropriate if 1 data set from a pair is estimated or known (Alldredge et al. 1998), we compared individual stomach contents to intestinal contents of 10 damselfish, and stomach contents estimated as the average over 10 damselfish to fecal compositions averaged per individual ( $\mathrm{n}=6$ individual, 29 samples in total). Because of the lower acidity in the intestine $(\mathrm{pH}=6.97 \pm 0.3$, average $\pm \mathrm{SD})$ compared to the stomach $(\mathrm{pH}=2.7 \pm 0.15)$ of Stegastes nigricans (Lobel 1981), algae whose cell walls were not broken in the intestine were considered to be undigested.

\section{RESULTS}

We observed damselfish picking up specific algae inside their territory and discarding them outside the territory. The fish removed algae $0.54 \pm 0.85$ (average $\pm \mathrm{SD}, \mathrm{n}=7$ individuals, 21 observations each) times in $10 \mathrm{~min}$, regardless of time and tidal conditions during the day (2-way ANOVA: $F_{3}=0.26, F_{3}=0.12$, respectively, both non-significant).

Eighty-eight samples discarded by 12 damselfish contained 17 species of algae. The 9 major species are shown in Fig. 2A. The other 8 species (Caulerpa serrulata, Struvea sp., Enteromorpha sp., Polysiphonia coacta, Centroceras clavulatum, Jania sp., Callithamnion sp. and Corallophila huysmansii) were quite rare both in discarded algae $(<1 \%)$ and inside the territories $(<0.1 \%)$. Compared to the algae found inside the territory (Fig. 2B), overall weeding selectivity was sig- 
nificant (Snedecor's $F$-test: $F_{8,4}=22.6, \quad p<0.01$; Fig. $2 \mathrm{C}$ ), suggesting highly selective weeding by the fish. An articulated calcareous rhodophyte, Jania adhaerens, was most selectively weeded out, followed by the relatively thick and coarsely branched rhodophytes Gelidiopsis variabilis, Chondria sp. and Gelidiella pannosa. Digestibility differed among algal species (Snedecor's F-test: $F_{8,8}=10.4, \mathrm{p}<0.01$; Fig. 2D). The dominant alga in Stegastes nigricans territories, the thin and finely branched filamentous rhodophyte Womersleyella setacea $(57.7 \pm 21.2 \%$ in biomass, $\mathrm{n}=5$ ), was the most digestible and the least frequently weeded. In contrast, the algae that were more selectively weeded out by the fish were less digestible.

Stegastes nigricans ingested algae $68.9 \pm 27.4$ (average $\pm \mathrm{SD}, \mathrm{n}=7$ individuals, 21 observations each) times in $10 \mathrm{~min}$, exclusively in the algal farm. S. nigricans ingested almost exclusively Womersleyella setacea. However, W. setacea constituted only $16.7 \pm$ $27.5 \%(\mathrm{n}=11)$ of stomach contents, probably due to its high digestibility.

\section{DISCUSSION}

Stegastes nigricans intensively and highly selectively weeded out specific algae. Selectively weeded algae, such as the calcareous Jania adhaerens and the relatively thick and coarsely branched rhodophytes Gelidiopsis variabilis, Chondria sp., and Gelidiella pannosa were relatively indigestible to this damselfish. Calcareous algae such as Jania spp., which contain little energy, few nutrients, and a high percentage of ash, are not suitable food for most herbivorous fishes (Littler \& Littler 1980, Montgomery \& Gerking 1980). Gelidium pulchellum, a rhodophyte similar to these thick and coarsely branched rhodophytes in morphology, is highly resistant to acid lysis (Lobel 1981). Such thicker rhodophytes seem to be indigestible by damselfish, which lack tritulation mechanisms and depend on acid lysis for digestion (Lobel 1980). These selectively weeded algae are competitively superior species that colonize later than filamentous rhodophytes such as Womersleyella spp. (Littler \& Littler 1980, Littler et al. 1983, Steneck \& Dethier 1994, Hixon \& Brostoff 1996, Ferreira et al. 1998); this can result in considerable invasions of late-colonizers in the farms of some damselfishes (Hixon \& Brostoff 1996, Ferreira et al. 1998). Selective weeding by $S$. nigricans prevented these late-colonizing species from out-competing $W$. setacea and held algal succession at an earlier stage. The dominance of $W$. setacea in the farm enabled the $S$. nigricans to harvest nutritious and digestible algae effectively.
The virtual monoculture of an early-colonizing alga maintained by selective weeding is unique among resident herbivorous damselfishes, which typically have species-rich farms that are contaminated by late-colonizing species. An eastern Pacific damselfish, Microspathodon dorsalis, maintains a virtual monocultural farm of Polysiphonia sp. (comprising more than $90 \%$ ) by intensive and nonselective grazing instead of by weeding, but its farm is quite low in biomass (Montgomery 1980a,b). M. dorsalis holds a small territory $\left(0.51 \mathrm{~m}^{2}\right)$ relative to its body size $(220 \mathrm{~mm}$, TL; Montgomery 1980a,b), indicating that the monoculture farm of an early-colonizing alga may be adaptive under a strong limitation of territory size, because earlycolonizing algae are more productive (Montgomery 1980b, Klumpp et al. 1987, Branch et al. 1992), more digestible, and more nutritious than late-colonizing species (Littler \& Littler 1980, Montgomery \& Gerking 1980 ), and a monoculture of these algae could yield more per area.

Stegastes lividus and S. planifrons, which extensively weed out some algae, maintain species-rich farms. Inside the territory of $S$. lividus, the filamentous rhodophyte Polysiphonia scopulorum and the coarsely branched rhodophyte Gelidiopsis intricata together comprised $40 \%$ of the algal crop (Lassuy 1980), and inside the territory of $S$. planifrons, the early colonizers Polysiphonia spp., filamentous green algae and diatoms were abundant and competed with a latecolonizing species, Coelothrix irregularis (Irvine 1982). The difference in species diversity in the farms of these 2 damselfish species and $S$. nigricans may indicate that weeding by $S$. nigricans is particularly intensive and selective, and that it strongly affects algal assemblages in favor of enhanced yields from its territory.

In conclusion, Stegastes nigricans weeds out unpalatable and competitively superior late-colonizing algae to maintain a virtual monocultural crop of a digestible early-colonizer, Womersleyella setacea. This alga is found almost exclusively in the territories of the fish and is quite rarely found outside the territories in the reef. Thus, the management of farms by intensive weeding is the first example of a mutual interaction between a herbivore and its crop alga.

Acknowledgements. We thank Prof. M. Nishihira for introducing marine ecology to us, the Sesoko Marine Science Center (SMSC), and the University of the Ryukyus provided the facilities for field research and the laboratory. We thank Dr. K. Nakata for his significant suggestions and discussion. We are grateful to S. Sakai, Y. Shigemiya, A. Takimura, K. Yamasaki, A. Kawakita and A. Nishikawa for their kind help, suggestions, discussion and encouragement. We are also grateful to the referees for their valuable help and comments. 


\section{LITERATURE CITED}

Alldredge JR, Thomas DL, McDonald LL (1998) Survey and comparison of methods for study of resource selection. J Agric Biol Environ Stat 3:237-253

Branch GM, Harris JM, Parkins C, Bustamante RH, Eekhout S (1992) Algal 'gardening' by grazers: a comparison of the ecological effects of territorial fish and limpets. In: John DM, Hawkins SJ, Price JH (eds) Plant-animal interactions in the marine benthos. Clarendon Press, Oxford, p 405-423

Brawley SH, Adey WH (1977) Territorial behavior of threespot damselfish Eupomacentrus planifrons increases reef algal biomass and productivity. Environ Biol Fish 2:45-51

Ferreira CE, Gonçalves JE, Coutinho R, Peret AC (1998) Herbivory by the dusky damselfish Stegastes fuscus (Cuvier, 1830 ) in a tropical rocky shore: effects on the benthic community. J Exp Mar Biol Ecol 229:241-264

Galetto MJ, Bellwood DR (1994) Digestion of algae by Stegastes nigricans and Amphiprion akindynos (Pisces: Pomacentridae), with an evaluation of methods used in digestibility studies. J Fish Biol 44:415-428

Hinds PA, Ballantine DL (1987) Effects of the Caribbean threespot damselfish, Stegastes planifrons (Cuvier), on algal lawn composition. Aquat Bot 27:299-308

Hixon MA, Brostoff WN (1983) Damselfish as keystone species in reverse: intermediate disturbance and diversity of reef algae. Science 220:511-513

Hixon MA, Brostoff WN (1996) Succession and herbivory: effects of differential fish grazing on Hawaiian coral-reef algae. Ecol Monogr 66:67-90

Horn MH (1992) Herbivorous fishes: feeding and digestive mechanisms. In: John DM, Hawkins SJ, Price JH (eds) Plant-animal interactions in the marine benthos. Clarendon Press, Oxford, p 339-362

Irvine GV (1982) The importance of behavior in plantherbivore interactions. In: Cailliet GM, Simenstad CA (eds) Fish food habitat studies. University of Washington Sea Grant Press, Washington, p 240-248

Johnson DH (1980) The comparison of usage and availability measurements for evaluating resource preference. Ecology 61:65-71

Kamura S, Choonhabandit S (1986) Algal communities within territories of the damselfish Stegastes apicalis and the effects of grazing by the sea-urchin Diadema spp. in the Gulf of Thailand. Galaxea 5:175-194

Karino K, Nakazono A (1993) Reproductive behavior of the territorial herbivore Stegastes nigricans (Pisces: Pomacentridae) in relation to colony formation. J Ethol 11:99-110

Klumpp DW, Polunin NVC (1989) Partitioning among grazers of food resources within damselfish territories on a coral reef. J Exp Mar Biol Ecol 125:145-169

Klumpp DW, McKinnon D, Daniel P (1987) Damselfish territo-

Editorial responsibility: Otto Kinne (Editor),

Oldendorf/Luhe, Germany ries: zones of high productivity on coral reefs. Mar Ecol Prog Ser 40:41-51

Lassuy DR (1980) Effects of 'farming' behavior by Eupomacentrus lividus and Hemiglyphidodon plagiometopon on algal community structure. Bull Mar Sci 30:304-312

Letourneur Y, Galzin R, Harmelin-Vivien M (1997) Temporal variations in the diet of the damselfish Stegastes nigricans (Lacepède) on a Réunion fringing reef. J Exp Mar Biol Ecol 217:1-18

Littler MM, Littler DS (1980) The evolution of thallus form and survival strategies in benthic marine macroalgae: field and laboratory tests of a functional form model. Am Nat 116:25-44

Littler MM, Taylor PR, Littler DS (1983) Algal resistance to herbivory on a Caribbean Barrier Reef. Coral Reefs 2:111-118

Lobel PS (1980) Herbivory by damselfishes and their role in coral reef community ecology. Bull Mar Sci 30:273-289

Lobel PS (1981) Trophic biology of herbivorous reef fishes: alimentary $\mathrm{pH}$ and digestive capabilities. J Fish Biol 19: 365-397

McShane PE, Smith MG (1988) Measuring abundance of juvenile abalone, Haliotis rubra Leach (Gastropoda: Haliotidae); comparison of a novel method with two other methods. Aust J Mar Freshw Res 39:331-336

Montgomery WL (1980a) Comparative feeding ecology of two herbivorous damselfishes (Pomacentridae: Teleostei) from the Gulf of California, Mexico. J Exp Mar Biol Ecol 47: $9-24$

Montgomery WL (1980b) The impact of non-selective grazing by the giant blue damselfish, Microspathodon dorsalis, on algal communities in the Gulf of California, Mexico. Bull Mar Sci 30:290-303

Montgomery WL, Gerking SD (1980) Marine macroalgae as foods for fishes: an evaluation of potential food quality. Environ Biol Fish 5:143-153

Pankratz C (1994) PREFER-Preference assessment v5.1 (Windows, OS2). Northern Prairie Science Center, North Pakota

Russ GR (1987) Is rate of removal of algae by grazers reduced inside territories of tropical damselfishes? J Exp Mar Biol Ecol 110:1-17

Ruyter van Steveninck EDde (1984) The composition of algal vegetation in and outside damselfish territories on a Florida reef. Aquat Bot 20:11-19

Sammarco PW (1983) Effects of fish grazing and damselfish territoriality on coral reef algae. I. Algal community structure. Mar Ecol Prog Ser 13:1-14

Steneck RS, Dethier MN (1994) A functional group approach to the structure of algal-dominated communities. Oikos 69:476-498

Vine PJ (1974) Effects of algal grazing and aggressive behaviour of the fishes Pomacentrus lividus and Acanthurus sohal on coral-reef ecology. Mar Biol 24:131-136

Submitted: January 30, 2002; Accepted: April 23, 2002

Proofs received from author(s): July 1, 2002 